\title{
High litterfall in old-growth and secondary upper montane forest of Costa Rica
}

\author{
Lars Köhler · Dirk Hölscher · Christoph Leuschner
}

Received: 25 October 2007 / Accepted: 19 March 2008/Published online: 31 March 2008

(C) The Author(s) 2008

\begin{abstract}
Tropical upper montane forests usually comprise trees of small stature with a relatively low aboveground productivity. In contrast to this rule, in the Cordillera de Talamanca (Costa Rica), tall trees ( $>35 \mathrm{~m}$ in height and more than $60 \mathrm{~cm}$ in diameter) are characteristic for the upper montane old-growth oak forests which are growing at an altitude of almost $3,000 \mathrm{~m}$ close to the alpine timberline. For these exceptional forests, productivity data are not yet available. In this study, we analyzed litterfall and its components (tree leaves, litter of epiphytic vascular and non-vascular plants, mistletoes, twigs and other canopy debris) in three forest stands belonging to different successional stages and related seasonal changes in litterfall to micrometeorological variables. The studied stands were early-successional forest (1015-year-old), mid-successional forest (40-year-old), and old-growth forest. The stands are dominated by Quercus copeyensis and are located at 2,900-m altitude. Total litterfall was highest in the mid-successional forest $\left(1,720 \mathrm{~g} \mathrm{~m}^{-2} \mathrm{y}^{-1}\right)$, and reached $1,288 \mathrm{~g} \mathrm{~m}^{-2} \mathrm{y}^{-1}$ in
\end{abstract}

L. Köhler $(\bowtie) \cdot$ C. Leuschner

Plant Ecology, Albrecht-von-Haller-Institute for Plant

Sciences, University of Göttingen, Untere Karspüle 2,

37073 Göttingen, Germany

e-mail: koehlerlars@hotmail.com

D. Hölscher

Tropical Silviculture and Forest Ecology,

Burckhardt-Institute, University of Göttingen,

Büsgenweg 1, 37077 Göttingen, Germany the old-growth forest and $934 \mathrm{~g} \mathrm{~m}^{-2} \mathrm{y}^{-1}$ in the earlysuccessional forest. Litter mass was dominated by leaves in all stages (56-84\% of total litterfall). In the oldgrowth forest, however, twigs and small canopy debris particles (33\%), epiphytes (6\%), and mistletoes $(5 \%)$ also contributed substantially to litter mass. Leaf litterfall showed a clear seasonal pattern with a negative correlation to monthly precipitation and highest values in the dry season (January-April). However, the strongest correlation existed with minimum air temperature (negative), probably because temperatures already dropped at the end of the rainy season, when precipitation had not yet declined and leaf shedding already increased. In contrast, litterfall of epiphyte mass, and twigs and other debris was mostly dependent on occasional strong winds. We conclude that the upper montane oak forests of the Cordillera de Talamanca are exceptional with respect to the large tree size and the relatively high productivity as indicated by litterfall. Litter mass was especially high in the mid-successional and old-growth forests, where the observed annual totals are among the highest recorded for tropical forests so far.

Keywords Epiphytes - Forest succession Litter production $\cdot$ Quercus $\cdot$ Seasonality

\section{Introduction}

Tropical montane forests typically are built by trees of low canopy height and stem diameter, and a relatively 
low aboveground productivity (Whitmore 1998; Lamprecht 1986). In the Cordillera de Talamanca of Costa Rica, however, a montane oak forest type exists in which tall trees with more than $35 \mathrm{~m}$ in height and more than $60 \mathrm{~cm}$ in diameter prevail (Kappelle et al. 1996). Oaks of this size predominately occur on the west facing slopes and in areas over 2,400 $\mathrm{m}$ high, and are not found in other regions of the country. In addition to a presumed high aboveground biomass, these forests also have a high fine root biomass (Hertel et al. 2003). Although data are not available, one may assume that productivity is also relatively high in this high-elevation forest type.

Litterfall may provide an indication of aboveground forest productivity because it is one of its main components. In addition, litterfall is a major pathway in forest nutrient cycles, and gives information on tree phenology (Proctor 1983). Data on aboveground litter production in tropical forests are available for a considerable number of lowland sites and also for various montane stands. However, it is not yet clear how litter mass changes with elevation. Litterfall was found to be relatively low in some montane forests (Bruijnzeel and Proctor 1995; Heaney and Proctor 1989; Moser et al. 2007), whereas other studies suggest that there is no systematic change in litterfall with elevation (Clark et al. 2001; Kitayama and Aiba 2002). Most studies on litterfall in tropical forests refer to old-growth forests. The few available data for young successional forests indicate that litterfall in early- to mid-successional stages may be higher than in mature forests (Ewel 1976; Kellman 1970; Ong et al. 1981).

Litterfall in tropical montane forests may significantly depend on the abundance of epiphytes. This aspect has so far only rarely been addressed, and if so, only in old-growth forests (e.g. Nadkarni and Matelson 1992). Seasonality in epiphytic litterfall may follow other temporal patterns than tree leaf fall because it seems to be controlled by different micrometeorological parameters. Many studies on tree leaf litterfall found a clear seasonal pattern with high rates in the dry season (e.g. Proctor et al. 1989; Tanner 1980). However, maximum litterfall may also occur during the rainy season (Proctor et al. 1983), or no seasonal changes may exist at all (Medina and Klinge 1983; Steinhardt 1979; Veneklaas 1991).

This study was conducted in the upper montane forest belt of the Cordillera de Talamanca, where the old-growth forests are composed of tall tropical oak species. Similarly, the secondary forests are dominated by Quercus species as well (Kappelle et al. 1996). The old-growth forests are characterized by the abundance of non-vascular epiphytes (Köhler et al. 2008). Study objectives were (1) to quantify litterfall and its components (tree leaves, epiphytic vascular and non-vascular plants, mistletoes, twigs and other canopy debris) in three successional stages, and (2) to analyze the seasonality of litterfall of the various components and its control by micrometeorological factors.

\section{Methods}

Study sites

The study was conducted in the Los Santos Forest Reserve located on the Pacific slope of the Cordillera de Talamanca in Costa Rica $\left(9^{\circ} 35^{\prime} 40^{\prime \prime} \mathrm{N}, 83^{\circ} 44^{\prime}\right.$ $30^{\prime \prime} \mathrm{W}$ ). The sites were situated in the upper montane forest belt of the Los Santos Forest Reserve at an elevation of ca. 2,900 $\mathrm{m}$ a.s.l. Three study plots were selected: a 10-15-year-old early-successional forest (ESF), a 40-year-old mid-successional forest (MSF), and an old-growth forest (OGF). The ESF and MSF stands were separated from each other by $200 \mathrm{~m}$. The OGF stand was about $2 \mathrm{~km}$ distant from the others. The selected plots were similar in slope $\left(25-31^{\circ}\right)$; the ESF and MSF plots were exposed southward, whereas the OGF showed a NE aspect. Annual average temperature at a station $15 \mathrm{~km}$ east of the study sites (Villa Mills, $3,000 \mathrm{~m}$ a.s.1.) is $10.9^{\circ} \mathrm{C}$. Annual average rainfall is 2,812 mm; a dryer season occurs between December and April with average monthly precipitation of about $30 \mathrm{~mm}$ (January-March) and $100 \mathrm{~mm}$ (December and April) (Instituto Meteorológico Nacional 1988). Additional inputs via horizontal precipitation at these relatively sheltered sites are considered to be small (Köhler 2002). The soils of the study region are classified as Humic Andosols (FAO system) or Hapludands (USDA system) (Van Uffelen 1991; Kennis and De Vries 1993).

The OGF had previously been described as "primary forest" or "mature forest" (Kappelle et al. 1995, 1996). Stem density (trees $\geq 3 \mathrm{~cm} \mathrm{DBH}$, diameter at breast height) was 5,730, 4,800, and 3,460 $\mathrm{n} \mathrm{ha}^{-1}$ in ESF, $\mathrm{MSF}$, and OGF, respectively. Average tree basal area 
was $5 \mathrm{~m}^{2} \mathrm{ha}^{-1}$ in various ESF stands, $18 \mathrm{~m}^{2} \mathrm{ha}^{-1}$ in the MSF stands and $57 \mathrm{~m}^{2} \mathrm{ha}^{-1}$ in the OGF stands (Kappelle et al. 1996). The height of the upper tree layer in the three stands of our study was about 5-9 $\mathrm{m}$ in the ESF, $11-15 \mathrm{~m}$ in the MSF, and 30-35 $\mathrm{m}$ in the OGF where single trees of even larger height occurred. There was only one tree layer in the secondary forests while there were two to three in the OGF. The stands were dominated by Quercus copeyensis (C.H. Müll.). In the old-growth forest, a second oak species $(Q$. costaricensis Liebm.) was also abundant. The ESF site was more species rich and contained more than 15 tree and shrub species on a $40 \mathrm{~m} \times 40 \mathrm{~m}$ plot. Beside Quercus copeyensis and $Q$. costaricensis, species from the genera Oreopanax, Viburnum, Myrsine, Weinmannia, Cleyera, Styrax, Cornus, and others were present. The overall diversity of epiphytic bryophytes and macrolichens was high with a similar number of species occurring in the three forest stands (168 species in total; Holz 2006). At the stand level, the total epiphyte biomass increased with stand age from $160 \mathrm{~kg}$ dry weight ha ${ }^{-1}$ in ESF to $520 \mathrm{~kg} \mathrm{ha}^{-1}$ in MSF and $3,400 \mathrm{~kg} \mathrm{ha}^{-1}$ in OGF (Köhler et al. 2008). In all stands, epiphytic vegetation was dominated by nonvascular plants (bryophytes and lichens) which accounted for $99 \%$ (ESF), $89 \%$ (MSF), and 70\% (OGF) of the total epiphyte biomass (including canopy humus).

Measurements of micrometeorological parameters and precipitation

Micrometeorological parameters were automatically recorded at an open field adjacent to the successional forest sites. Air temperature and relative humidity (MP 100 A, Rotronic, Ettlingen, Germany; instruments well shielded) and wind speed (anemometer type 4.3519.00, Thies, Göttingen, Germany) were measured at $1.5 \mathrm{~m}$ above the ground. Data were sampled in 10-s intervals with a CR10X datalogger (Campbell, Shepshed, UK) and averaged every $10 \mathrm{~min}$. Incident rainfall was recorded weekly on two clearings; the size of each clearing was several thousand square meters. One clearing was located in direct proximity of the early- and mid-successional forest stands adjacent to the micrometeorological station, the other was close to the old-growth forest. Five rainfall samplers at a height of $70 \mathrm{~cm}$ (aperture: $213.8 \mathrm{~cm}^{2}$ ) were used on each clearing.

\section{Litter sampling}

Litterfall was collected at 4-week intervals during a full year (April 1999-April 2000) with ten, systematically distributed litter traps $\left(2500-\mathrm{cm}^{2}\right.$ aperture) in each stand. The litter traps were made of plastic gauze bags (2-mm mesh width) which were attached to wooden frames of $50 \mathrm{~cm}$ by $50 \mathrm{~cm}$. They were placed horizontally at a height of about $0.5 \mathrm{~m}$ at regular intervals along three transects that run parallel to the contour lines within the 50-m long and 20-m wide study plot. On the upslope side of each trap a net was spread on the soil to avoid litter inputs from the steep slope above. To investigate seasonal dynamics of litter production, the traps were emptied precisely in intervals of 4 weeks (28 days) during the 12-month period. This schedule resulted in 13 sampling periods that do not correspond exactly to the months. Precipitation and other micrometeorological data were related to these sampling periods and therefore might differ slightly from data published before on the "real" month basis. The collected litter was transferred to the laboratory and separated into the following fractions: leaves, epiphytic vascular plants, epiphytic non-vascular plants (mosses, liverworts, and lichens), mistletoes, twigs and debris (which consists of twigs $<2 \mathrm{~cm}$ in diameter, flowers, fruits, and unrecognizable organic matter particles from the canopy).

All litter samples were dried $\left(70^{\circ} \mathrm{C}, 48 \mathrm{~h}\right)$ and weighed. To determine the percentage of oak leaves, leaves of Quercus copeyensis and $Q$. costaricensis were separated from leaves of other tree species from November 1999 to April 2000 in all leaf samples.

Statistical analyses

A Wilcoxon U-test, $P<0.05$ (epiphytic vascular plants) and a Scheffé-test, $P<0.05$ (other litter fractions) were used to determine whether significant differences existed between litter values measured in the three stands. Regressions between monthly litterfall values and microclimatological variables were calculated with the computer program Xact (Sci-Lab, Germany). Additionally, multiple linear regression models were applied using SAS software (SAS Institute Inc., Cary, NC, US; version 8.2). 


\section{Results}

Micrometeorological parameters and precipitation

Rainfall during the study period did not differ much from the long-term average $\left(2,812 \mathrm{~mm} \mathrm{y}^{-1}\right)$ (Instituto Meteorológico Nacional 1988). It was $3,049 \mathrm{~mm} \mathrm{y}^{-1}$ on the successional forest clearing and 3,002 $\mathrm{mm} \mathrm{y}^{-1}$ on the clearing close to the OGF. Highest monthly precipitation was recorded at both stations in April 1999 with $431 \mathrm{~mm}$ (successional forest clearing) and $503 \mathrm{~mm}$ on the OGF clearing (Fig. 1a). During the dry season, the lowest precipitation within a 28 -d period was $20 \mathrm{~mm}$ on the successional forest clearing and $25 \mathrm{~mm}$ on the OGF clearing.

Seasonality in temperature was low with the warmest period (May) exceeding the coldest month (January) in mean temperature by only $1.8 \mathrm{~K}$. Absolute minimum temperature showed similar values of about $6^{\circ} \mathrm{C}$ during the rainy season; it was up to $4 \mathrm{~K}$ lower during the dry season (Fig. 1b). At ground level, frost was not uncommon during the dry season. Absolute maximum temperature differed only by $2.5 \mathrm{~K}$ during the year $\left(20.6-23.1^{\circ} \mathrm{C}\right)$. The absolute maximum of vapor pressure deficit (VPD) was between 12 and $16 \mathrm{hPa}$ during the rainy season and up to $23 \mathrm{hPa}$ during the dry season. During most of the year, the maximum wind speed (10-min averages) ranged between 2 and $4 \mathrm{~m} \mathrm{~s}^{-1}$ but reached higher values $\left(>5 \mathrm{~m} \mathrm{~s}^{-1}\right)$ in November (Fig. 1c). Single strong gusts, which were not recorded due to the automatic calculation of mean values, must have reached much higher velocities, especially in the tree canopies.

\section{Annual litterfall}

Total annual litterfall was $934 \mathrm{~g} \mathrm{~m}^{-2} \mathrm{y}^{-1}$ in the ESF, $1,720 \mathrm{~g} \mathrm{~m}^{-2} \mathrm{y}^{-1}$ in the MSF, and $1,288 \mathrm{~g} \mathrm{~m}^{-2} \mathrm{y}^{-1}$ in the OGF (Table 1). In all three stands leaves were the dominating litter fraction and accounted for $84 \%$, $73 \%$, and $56 \%$ of total litter mass in the ESF, MSF, and OGF stands, respectively. While the percentage of leaf litter in total litter mass was decreasing with stand age, the proportion of all other litter fractions increased in this direction.

Litterfall of epiphytes increased with stand age and showed significantly higher values in OGF when compared to the secondary forests. In the OGF stand,
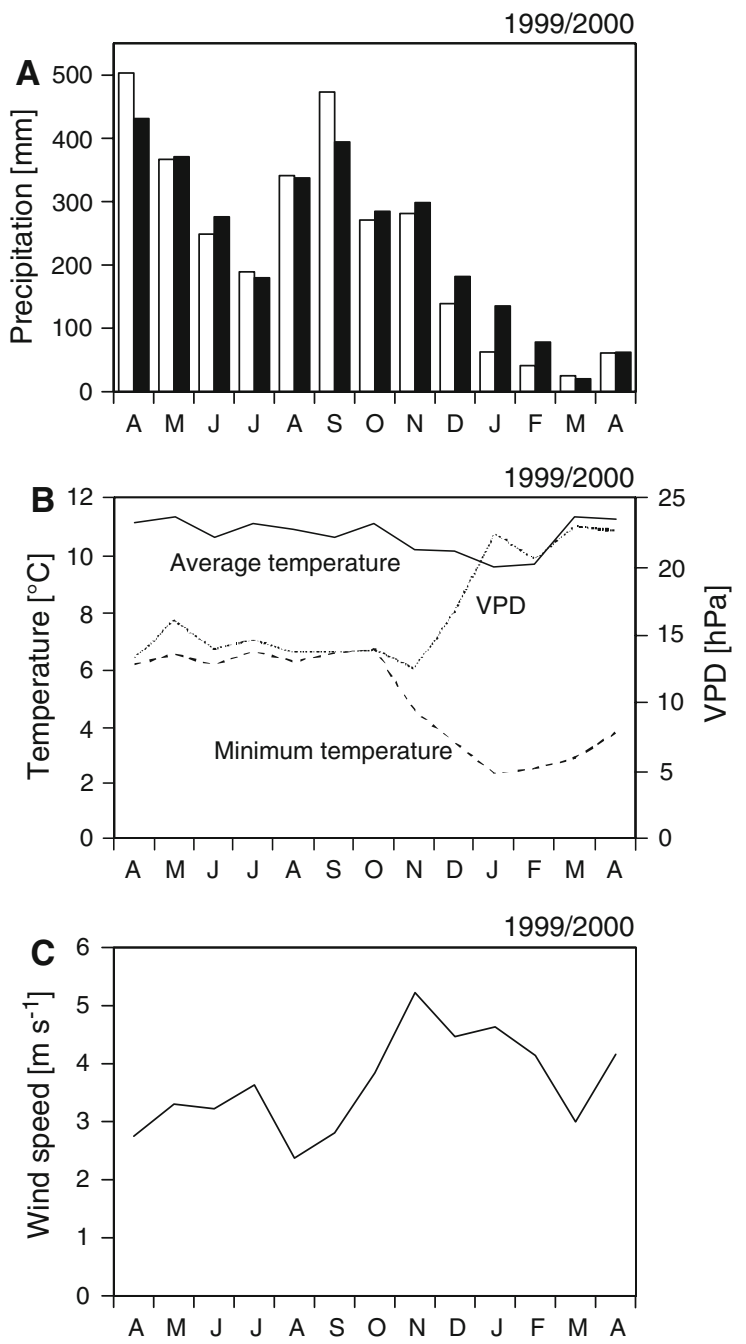

Fig. 1 (a) Monthly rainfall on a clearing close to the earlyand mid-successional forests (black bars) and on a clearing close to the old-growth forest (white bars). (b) Average temperature, absolute minimum temperature and absolute VPD maximum on a clearing close to the successional forests. (c) Maximum wind speed. Indicated in $\mathbf{a}-\mathbf{c}$ are sampling periods of 28 days that do not exactly correspond to the months

litterfall of vascular epiphytes exceeded the corresponding values of ESF and MSF by factors of 29 and 11, respectively. Litterfall of non-vascular epiphytes was 10- and 4-fold higher in OGF than in ESF and MSF. The contribution of epiphytes to total litterfall was low with $0.5 \%$ in the ESF and $0.7 \%$ in the MSF stands, but accounted for $6.1 \%$ in the OGF. Especially vascular epiphytes showed a high spatial and temporal heterogeneity of litterfall as expressed by high standard errors. In the OGF, litter of a mistletoe 
Table 1 Annual litterfall of leaves, twigs (diameter $<2 \mathrm{~cm}$ ), and other debris (including mistletoes), epiphytic non-vascular plants, epiphytic vascular plants, and total litterfall in the studied early-successional forest (ESF), mid-successional forest (MSF), and old-growth forest (OGF) (means $\pm \mathrm{SE}$ )

\begin{tabular}{|c|c|c|c|}
\hline & \multicolumn{3}{|c|}{ Annual litterfall $\left[\mathrm{g} \mathrm{m}^{-2} \mathrm{y}^{-1}\right]$} \\
\hline & ESF & MSF & OGF \\
\hline Tree leaves & $787 \pm 66 \mathrm{a}$ & $1,259 \pm 77 b$ & $720 \pm 40 \mathrm{a}$ \\
\hline Twigs and debris & $142 \pm 22 \mathrm{a}$ & $449 \pm 50 \mathrm{~b}$ & $489 \pm 32 b$ \\
\hline $\begin{array}{l}\text { Epiphytic non- } \\
\text { vascular plants }\end{array}$ & $3 \pm 1 \mathrm{a}$ & $8 \pm 2 a$ & $35 \pm 2 b$ \\
\hline $\begin{array}{l}\text { Epiphytic } \\
\quad \text { vascular plants }\end{array}$ & $2 \pm 1 \mathrm{a}$ & $4 \pm 1 \mathrm{a}$ & $44 \pm 8 b$ \\
\hline Total litterfall & $934 \pm 78 \mathrm{a}$ & $1,720 \pm 118 \mathrm{~b}$ & $1,288 \pm 61 \mathrm{a}$ \\
\hline
\end{tabular}

Significantly different means between the forest types are indicated by different letters. Epiphytic vascular plants: Wilcoxon U-test, $P<0.05$; other litter fractions: Scheffé-test, $P<0.05$

Fig. 2 Mean monthly litterfall of leaves (bars) and total litterfall (shaded area) and of twigs and debris (including mistletoes) in the early-successional forest (ESF), mid-successional forest (MSF), and oldgrowth forest (OGF). The sampling periods $(28 \mathrm{~d})$ do not exactly correspond to the months
(Phoradendron spp.) accounted for about 5\% of total litterfall, while it was virtually absent $\left(<1 \mathrm{~g} \mathrm{~m}^{-2} \mathrm{y}^{-1}\right)$ in the two successional forests.

\section{Seasonality of litterfall}

Leaf litter showed a distinct seasonality with highest monthly values at the beginning of the dry season and much lower quantities in the rainy season (Fig. 2). In all stands, highest values of leaf litter were measured in January when the amount of leaf litter exceeded the minimum values of August by factors of 4, 6, and 12 in ESF, MSF, and OGF, respectively.

In January, when leaf litterfall peaked, percentage of oak leaves was very high in the MSF and OGF stands (97 and $95 \%$ of total leaf litter; Table 2). In month with lower leaf litterfall (e.g. April 2000) oak leaves contributed with a lower percentage to the

(n)
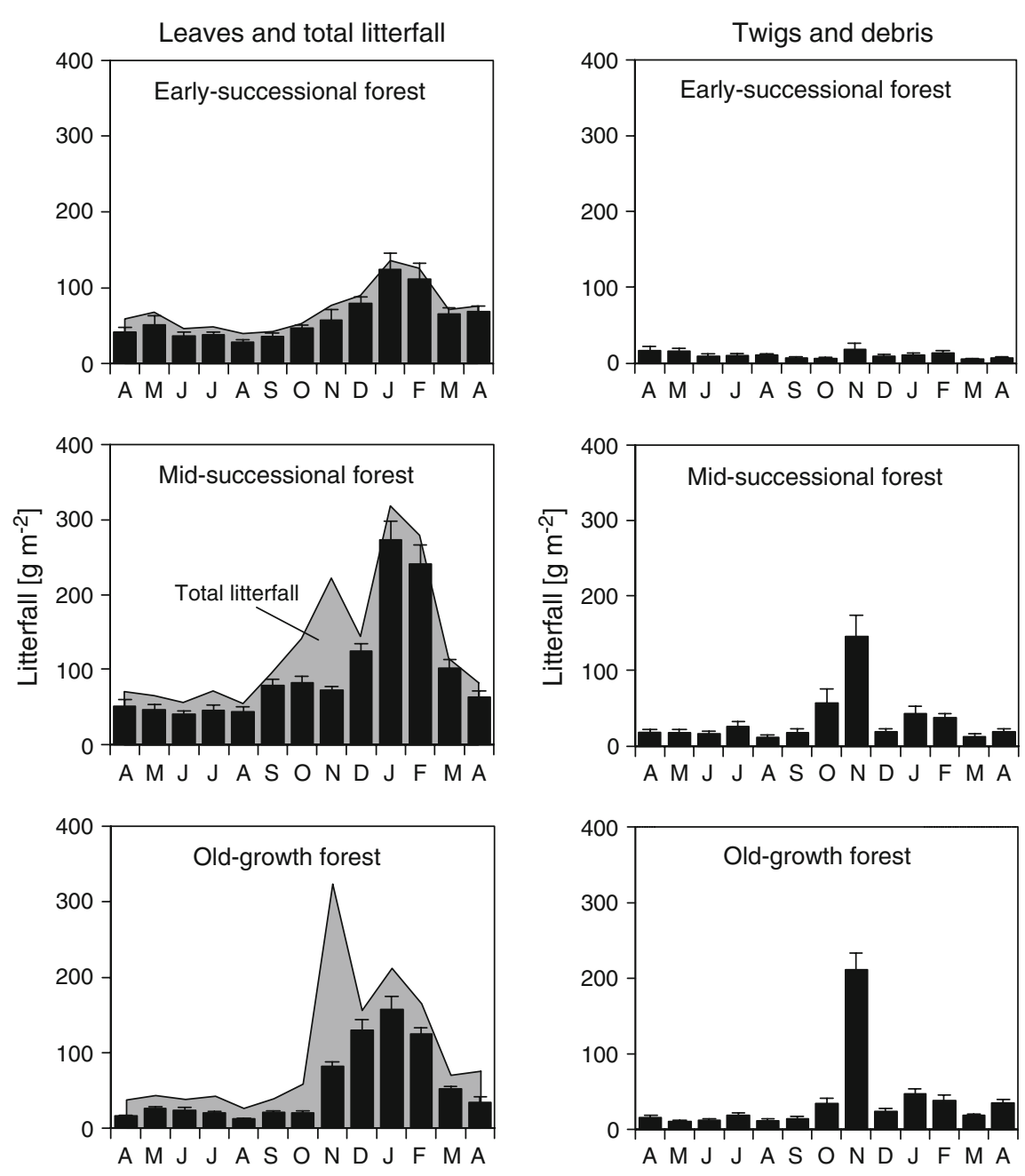
Table 2 Percentage of oak leaves (mainly Quercus copeyensis) in the leaf litter mass in the early-successional forest (ESF), mid-successional forest (MSF), and old-growth forest (OGF) from November 1999 to April 2000 (means \pm SE)

\begin{tabular}{llcl}
\hline & \multicolumn{3}{l}{ Oak leaves $[\%$ of total leaf litter] } \\
\cline { 2 - 4 } & ESF & MSF & OGF \\
\hline November & $49 \pm 10$ & - & $83 \pm 4$ \\
December & $59 \pm 6$ & $91 \pm 8$ & $94 \pm 1$ \\
January & $62 \pm 8$ & $97 \pm 2$ & $95 \pm 1$ \\
February & $40 \pm 6$ & $95 \pm 4$ & $96 \pm 1$ \\
March & $19 \pm 8$ & $88 \pm 7$ & $86 \pm 3$ \\
April & $31 \pm 9$ & $78 \pm 8$ & $56 \pm 4$ \\
\hline
\end{tabular}

total amount of leaf litter (78\% in MSF and 56\% in OGF). In the ESF stand, where oak species were also abundant but less dominant, Quercus leaves contributed by $62 \%$ to the total amount of leaf litter in January. In March, when total litterfall was low in this stand, the percentage of oak leaves was also relatively low (19\%).

Because of the dominance of leaf litter, total litterfall in most sampling periods showed a similar pattern as leaves except for November (Fig. 2). Due to the high amount of twigs and debris in the MSF and OGF stations (Fig. 2), total litterfall exceeded the amount of leaf litter by a factor of 3 (MSF) and 4 (OGF) during this period. In the ESF, litterfall of twigs and debris was also highest in this period but contributed less to total litterfall due to the strong dominance of leaves in this stand (84\%). Litterfall of twigs and debris showed no clear seasonality but peaked during occasional periods of high wind speed (e.g. November; Fig. 1).
Fig. 3 Mean monthly litterfall of epiphytic vascular plants and of epiphytic non-vascular plants in the earlysuccessional forest (ESF), mid-successional forest (MSF), and old-growth forest (OGF). The sampling periods (28 d) do not exactly correspond to the months
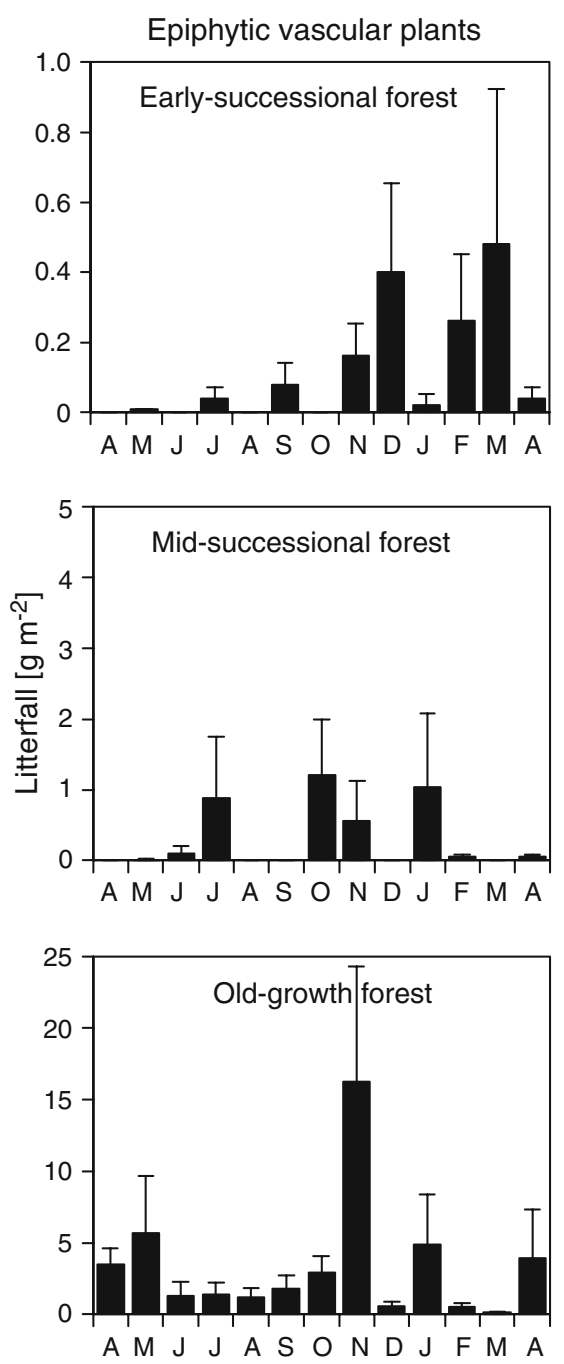
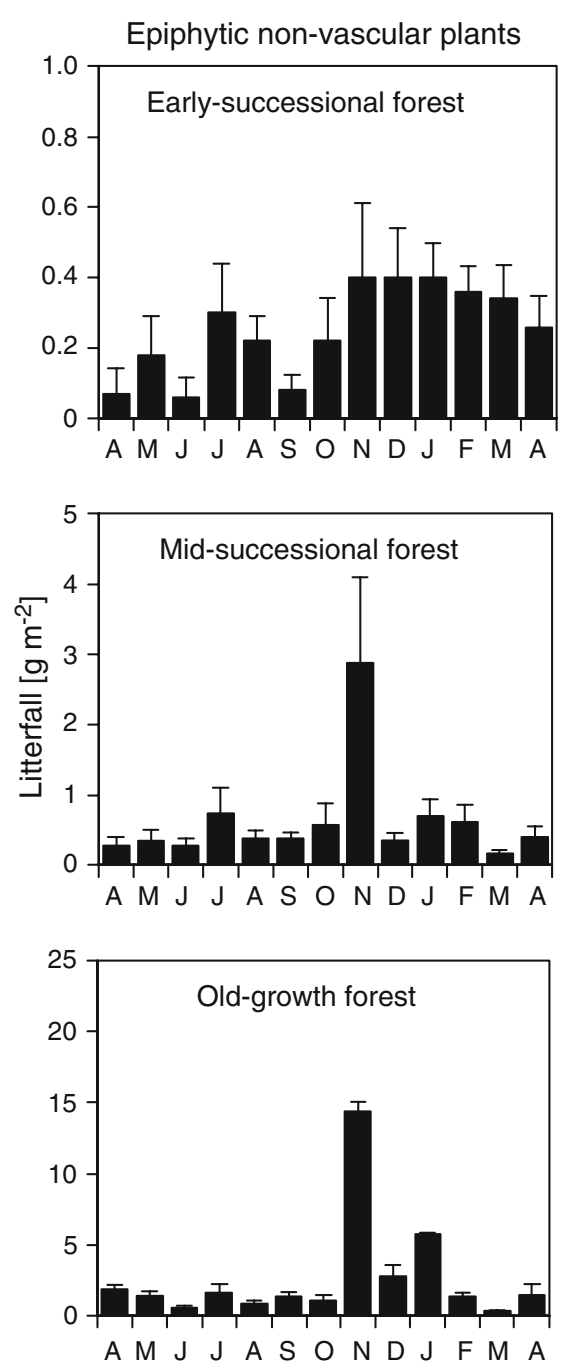
Table 3 Regression of monthly litterfall data on microclimatological variables (monthly means) in the studied early-successional forest (ESF), mid-successional forest (MSF), and old-growth forest (OGF). Maximum wind speed is given for 10-min averages

\begin{tabular}{|c|c|c|c|c|c|c|c|}
\hline & \multirow[t]{2}{*}{ Direction of effect } & \multicolumn{2}{|l|}{ ESF } & \multicolumn{2}{|l|}{ MSF } & \multicolumn{2}{|l|}{ OGF } \\
\hline & & $r_{\text {adj. }}^{2}$ & $P$ & $r_{\text {adj. }}^{2}$ & $P$ & $r_{\text {adj. }}^{2}$ & $P$ \\
\hline \multicolumn{8}{|l|}{ Leaf litterfall } \\
\hline Precipitation & - & 0.35 & $*$ & 0.20 & n.s. & 0.32 & $*$ \\
\hline Mean temperature & - & 0.45 & $* *$ & 0.60 & $* *$ & 0.71 & $* * *$ \\
\hline Absolute min. temperature & - & 0.77 & $* * *$ & 0.57 & $* *$ & 0.68 & $* * *$ \\
\hline Absolute max. temperature & & 0.05 & n.s. & 0.04 & n.s. & 0.08 & n.s. \\
\hline Absolute max. of VPD & + & 0.50 & $* *$ & 0.31 & $*$ & 0.19 & n.s. \\
\hline Max. wind speed & + & 0.34 & $*$ & 0.17 & n.s. & 0.46 & $* *$ \\
\hline \multicolumn{8}{|c|}{ Litterfall of epiphytic non-vascular plants } \\
\hline Max. wind speed & + & 0.47 & $* *$ & 0.93 & $* * *$ & 0.96 & $* * *$ \\
\hline \multicolumn{8}{|c|}{ Litterfall of epiphytic vascular plants } \\
\hline Max. wind speed & + & 0.00 & n.s. & 0.01 & n.s. & 0.81 & $* * *$ \\
\hline \multicolumn{8}{|l|}{ Litterfall of twigs and debris } \\
\hline Max. wind speed & + & 0.12 & n.s. & 0.87 & $* * *$ & 0.97 & $* * *$ \\
\hline
\end{tabular}

Given are adjusted regression coefficients, significance is indicated at $P<0.001^{* * *}, P<0.01 * *$, and $P<0.05^{*}$; n.s., not significant. Italic values represent exponential regressions; all other regressions are linear. + or - behind the variables indicate the direction of the effect

Similarly, the litterfall of epiphytic vascular and non-vascular plants showed no clear seasonal pattern and in most cases highest litterfall was measured in the sampling period of November (Fig. 3). For example, litterfall in the OGF was 7 times higher (epiphytic vascular plants) in November and more than 8 times higher (epiphytic non-vascular plants) as compared to the average litter production during the rest of the year. Within this 4 -week period $37 \%$ of the annual litterfall of epiphytic vascular plants and $42 \%$ of the annual litterfall of epiphytic non-vascular plants were measured in the OGF. In the two successional forests, litterfall of epiphytes during November was less pronounced with the exception of the litterfall of non-vascular epiphytes in the MSF which accounted for $35 \%$ of the annual total of this litter fraction in this month (Fig. 3).

Litterfall and its relation to micrometeorological parameters

In the MSF and the OGF stands, strong correlations existed between litterfall and some of the micrometeorological parameters (Table 3). Negative relationships were found between leaf litterfall and mean temperature and absolute minimum temperature in all stands; this indicates that litter production was higher in the dry season with lower temperatures. Negative correlations were also found between leaf litterfall and precipitation, while leaf litterfall was positively related to maximum VPD and maximum wind speed. No correlation was found between leaf litterfall and absolute maximum temperature. For leaf litter fall in the ESF, minimum temperature was the only significant parameter in a multiple linear regression and explained $79 \%$ of the variation observed. In the MSF $87 \%$ of the variation in leaf litterfall can be explained by average temperature $(63 \%)$ and VPD (24\%). In the OGF average temperature $(73 \%)$ and minimum temperature (18\%) explained $91 \%$ of the variation observed in leaf litterfall.

Litterfall of vascular and non-vascular epiphytes in the OGF was highly influenced by wind speed as indicated by the strong correlation between maximum wind speed and litterfall in this stand (Table 3). In the MSF stand, a strong correlation with wind speed was found for non-vascular epiphytes while no relationship existed between wind and litter in the case of vascular epiphytes. In the ESF, where biomass of epiphytes was low, litterfall of epiphytes was much less influenced by wind (Table 3). There was no correlation between litterfall of epiphytes and temperature, VPD, or precipitation. A close correlation existed between 
litterfall of twigs and debris and maximum wind speed in the OGF and MSF stand. The multiple linear regression also confirms the strong impact of the wind on the litterfall of epiphytes. In the MSF $65 \%$ of the variation in litterfall of non-vascular epiphytes can be explained by wind (43\%) and VPD (22\%). In the OGF wind (51\%) and rainfall (18\%) explained $69 \%$ of the variation observed in litterfall of non-vascular epiphytes. In the ESF probably due to the very low biomass of non-vascular epiphytes there was no significant influence of the wind but minimum temperature explained $53 \%$ of the observed variation. In the OGF $65 \%$ of the variation in litterfall of vascular epiphytes can be explained by wind (43\%) and VPD (22\%). In the secondary forests (ESF and MSF) where biomass of vascular epiphytes was low there was no impact of the factor wind and minimum temperature was the only significant parameter that explained $45 \%$ of the variation in litterfall both, in ESF and MSF.

\section{Discussion}

Litterfall in tropical montane forests

Litterfall in tropical upper montane forests has often been reported to be lower than in forests of lower elevations (Bruijnzeel and Proctor 1995; Heaney and Proctor 1989; Moser et al. 2007). Along an elevational transect at Volcán Barva (Costa Rica), which is not far from our study sites in the Cordillera de Talamanca, total litterfall at four different sites decreased continuously from $900 \mathrm{~g} \mathrm{~m}^{-2} \mathrm{y}^{-1}$ at $100 \mathrm{~m}$ a.s.l. to $530 \mathrm{~g}$ $\mathrm{m}^{-2} \mathrm{y}^{-1}$ at 2,600 $\mathrm{m}$ a.s.l. (Heaney and Proctor, 1989). In contrast, Kitayama and Aiba (2002) found no reduction in litterfall along an elevational transect from 700 to 3,060 m a.s.l. at Mt. Kinabalu (Malaysia). By comparing litterfall of 28 old-growth tropical forest sites, Clark et al. (2001) concluded that litterfall does not change systematically with elevation. This agrees with the results of a meta-analysis of leaf litter data from various tropical montane forests by Röderstein et al. (2005) who also did not find a significant elevational change in leaf litter mass between 1,000 and 3,060 $\mathrm{m}$ a.s.1. This data compilation of 18 montane forest stands revealed a mean leaf litterfall of $474 \mathrm{~g} \mathrm{~m}^{-2} \mathrm{y}^{-1}$ for old-growth tropical montane forests (Röderstein et al. 2005). The highest leaf litterfall was measured in a tropical montane forest in Ecuador (862 $\mathrm{g} \mathrm{m}^{-2} \mathrm{y}^{-1}$ at $1,890 \mathrm{~m}$ a.s.l.); these data, however, included a small fraction of non-leaf fine litter $<5 \mathrm{~mm}$ as well (Röderstein et al. 2005). These authors assume that litterfall quantities are still underestimated because a certain degree of decomposition may have taken place within the 6-week sampling intervals. Our leaf litterfall total for the OGF stand $\left(720 \mathrm{~g} \mathrm{~m}^{-2} \mathrm{y}^{-1}\right.$ at 2,900 $\mathrm{m}$ a.s.1.) thus seems to be the second highest value so far reported for tropical old-growth montane forests. However, there is a lack of studies on litterfall from upper montane forests since most studies were carried out at elevations well below 2,500 $\mathrm{m}$ a.s.l.

Data from young successional forests by Ewel (1976), Kellman (1970), and Ong et al. (1981) suggest that after 15 years (or even less) litterfall of leaves and other small particles may be as high as, or even higher than, in tropical mature forests. A comparison of litter production in 9 tropical montane secondary forests by McDonald and Healey (2000) also revealed a high average value of $1,170 \mathrm{~g} \mathrm{~m}^{-2} \mathrm{y}^{-1}$ for total litterfall. This average includes the extremely high value measured by Fournier and Comacho de Castro (1973) in a premontane secondary forest stand in Costa Rica $\left(2,700 \mathrm{~g} \mathrm{~m}^{-2} \mathrm{y}^{-1}\right)$. When excluding this study, the mean litterfall rate of secondary forests is $980 \mathrm{~g} \mathrm{~m}^{-2} \mathrm{y}^{-1}$. This is still higher than average litter production measured in montane old-growth forests (790 $\mathrm{m}^{-2} \mathrm{y}^{-1} ; 20$ studies, McDonald and Healey 2000). The litterfall amount of the ESF stand in our study $\left(934 \mathrm{~g} \mathrm{~m}^{-2} \mathrm{y}^{-1}\right)$ lies within the range of values reported for other secondary forests (700$1,250 \mathrm{~g} \mathrm{~m}^{-2} \mathrm{y}^{-1}$; excluding Fournier and Comacho de Castro (1973)) by McDonald and Healey (2000). The high litterfall measured in our MSF stand $\left(1,720 \mathrm{~g} \mathrm{~m}^{-2} \mathrm{y}^{-1}\right)$ exceeds this range significantly but is lower than the very high value found by Fournier and Comacho de Castro (1973).

Herbivory may significantly reduce litter mass collected in litter traps. Clark et al. (2001) estimated that herbivory results in an underestimation of leaf litter mass in tropical forests by about $12 \%$. We have no exact data on herbivory in our forest stands but based on observations of tagged leaves and leaves inside the litter traps, which showed only little signs of herbivory, we assume that mass loss due to herbivory must be relatively low in the studied stands. One reason for a low herbivory rate might be the relative low specific leaf area of the dominating 
oak species Quercus copeyensis and $Q$. costaricensis (74.1 and $67.6 \mathrm{~cm}^{2} \mathrm{~g}^{-1}$; Köhler 2002). Moreover, herbivory should be rather low in the cool mountain climate of the Cordillera de Talamanca, when compared to hot lowland environments.

Only few studies have quantified litterfall of epiphytes, which were, as far as we know, all conducted in mature forest. At four different sites of the Jamaican montane rain forest, Tanner (1980) reported 0.4 to $18 \mathrm{~g} \mathrm{~m}^{-2} \mathrm{y}^{-1}$ of epiphyte litterfall (mainly bromeliads). In a montane rainforest in Colombia, Veneklaas (1991) documented an epiphytic litterfall of 22 and $23 \mathrm{~g} \mathrm{~m}^{-2} \mathrm{y}^{-1}$ in two forest stands at different elevations $(2,550$ and 3,370 $\mathrm{m}$ a.s.l., respectively). Similar litter quantity of epiphytes $\left(23 \mathrm{~g} \mathrm{~m}^{-2} \mathrm{y}^{-1}\right)$ was measured in a cloud forest in Venezuela (Steinhardt 1979). The highest value reported so far $\left(50 \mathrm{~g} \mathrm{~m}^{-2} \mathrm{y}^{-1}\right)$ was found in a cloud forest in Monteverde, Costa Rica, by Nadkarni and Matelson (1992) which consisted by more than $75 \%$ of bryophytes. Epiphyte litterfall measured in our OGF stand $\left(79 \mathrm{~g} \mathrm{~m}^{-2} \mathrm{y}^{-1}\right)$ was higher than the value measured in Monteverde, despite a relatively small epiphyte biomass in the Talamanca OGF stand (3.4 $\mathrm{Mg} \mathrm{ha}^{-1}$ in the Talamanca $v s .33 .1 \mathrm{Mg} \mathrm{ha}^{-1}$ in Monteverde) (Köhler et al. 2008; Nadkarni et al. 2004). However, biomass and annual litterfall of epiphytes in different stands are not necessarily related to each other. Litter mass may also depend on species composition and species longevity, the structure of the host trees, the aerodynamic roughness of the stand, and wind speed. In our study, biomass and litterfall of epiphytes both increased with increasing stand age from ESF to OGF. The percentage of litterfall from epiphytic vascular plants in relation to total epiphytic litterfall increased with stand age (31\% ESF, 33\% MSF, 56\% OGF), thus reflecting the higher biomass of vascular epiphytes in the OGF (Köhler et al. 2008).

Since litterfall is one of the main pathways in the nutrient cycles of forests, it is often measured to quantify nutrient transfer from the plants to the forest floor. In our three forest stands, nutrient concentrations in leaf litter for most elements were in the range of values reported for other old-growth montane forests in the tropics (Heaney and Proctor 1989). Nutrient return with leaf litterfall was very high in comparison to other tropical montane forests, which was mainly due to the high amounts of leaf litter in these stands (Köhler et al. 2006). However, nutrient flux with litterfall of epiphytic non-vascular plants was low. It accounted for only $2-5 \%$ of the nutrient flux with leaf litter in the OGF while it was less than $1 \%$ in the two successional forests (Köhler et al. 2006). Compared with the nutrient input into the forest floor via net precipitation, the nutrient flux with leaf litterfall was 16-20 times larger for N, 4-10 for $\mathrm{Ca}$, and 2-4 for $\mathrm{Mg}$. Only $\mathrm{K}$ flux, which is often underestimated in litterfall due to leaching losses from the litter traps, showed about 2 times larger fluxes via net precipitation than by leaf litter for all three stands (Köhler et al. 2006).

Seasonal dynamics of litterfall

Studies in tropical rainforests have shown that litterfall may be either peak in dry periods (Proctor et al. 1989; Tanner 1980) or alternatively in the wettest season (Proctor et al. 1983). Other studies found subsequent litterfall peaks in the dry and also in the wet season (Röderstein et al. 2005), or identified no marked seasonal changes in litterfall at all (Medina and Klinge 1983; Steinhardt 1979; Veeneklaas 1991). Our results revealed a pronounced seasonal pattern in leaf litterfall with higher values at the beginning of the dry season and a strong dependence of litterfall on micrometeorological parameters. Because maximum litterfall occurred in January, when temperatures were relatively low, a strong negative correlation was found between temperature (mean and absolute minimum) and leaf litterfall. Low temperatures may play a key role as a trigger for the initiation of leaf abscission. Although there was a negative correlation between precipitation and leaf litter production, it is unlikely that decreasing precipitation plays a key role as a trigger for leaf litterfall in these montane oak forests. In the OGF, the increasing leaf litter production started already in November at the end of the rainy season when precipitation was still high $(281 \mathrm{~mm})$. During this month, the minimum temperature already had decreased by more than $2 \mathrm{~K}$ in comparison to the previous month.

Seasonality in leaf litterfall in the Cordillera de Talamanca was highly determined by tree species of the genus Quercus (mainly Quercus copeyensis, and to a lesser extent $Q$. costaricensis). The genus Quercus, on many sampling occasions accounted for over $90 \%$ of the total leaf litter and oak leaves were particularly frequent when total leaf litterfall 
was highest. The ESF stand where oaks are less dominant, showed a lower percentage of oak leaves and less pronounced seasonal dynamics in leaf litter production than the MSF and OGF stands.

The litterfall of epiphytes showed no clear seasonal pattern, which is in accordance with other studies that quantified seasonal litterfall of epiphytes (Steinhardt 1979; Tanner 1980; Veneklaas 1991; Nadkarni and Matelson 1992). Litterfall of vascular and non-vascular epiphytes in the OGF was highly influenced by sporadic strong winds as indicated by the tight correlation between maximum wind speed and litterfall in this stand. The lower wind influence in the two successional forests is probably a consequence of the lower epiphytic biomass in these stands and also their smaller aerodynamic roughness.

\section{Conclusions}

The old-growth oak forests in the high Cordillera de Talamanca are characterized by tall trees with a large basal area, which differs noticeably from many other tropical montane forests. We found that this forest is also remarkably productive in terms of annual litter mass produced. However, litterfall peaked in a $40-$ year-old secondary forest, where the observed values are among the highest recorded for tropical forest so far. In old-growth and secondary forests there was also a marked seasonality with high leaf litterfall during the dry season which was mainly attributed to the occurrence of oak trees.

Acknowledgments This study was supported by a grant from the German Science Foundation (DFG; HO 2119/1-3). The processing of the litter samples was carried out in a laboratory of the University of Costa Rica; the support of this institution is gratefully acknowledged.

Open Access This article is distributed under the terms of the Creative Commons Attribution Noncommercial License which permits any noncommercial use, distribution, and reproduction in any medium, provided the original author(s) and source are credited.

\section{References}

Bruijnzeel LA, Proctor J (1995) Hydrology and biochemistry of tropical montane cloud forests: what do we really know? In: Hamilton LS, Juvik JO, Scatena FN (eds) Tropical montane cloud forests. Ecological Studies 110. Springer, New York, pp 38-78
Clark DA, Brown S, Kicklighter DW et al (2001) Net primary production in tropical forests: an evaluation and synthesis of existing field data. Ecol Appl 11:371-384

Ewel JJ (1976) Litterfall and leaf decomposition in a tropical forest succession in eastern Guatemala. J Ecol 64:293-308

Fournier LA, Comacho de Castro L (1973) Producción y descomposición del mantillo en un bosque secundario húmedo de premontano. Rev Biol Trop 21:59-67

Heaney A, Proctor J (1989) Chemical elements in litter in forests on Volcán Barva, Costa Rica. In: Proctor J (ed) Mineral nutrients in tropical forest and savanna ecosystems. Blackwell Scientific Press, Oxford, pp 255-271

Hertel D, Leuschner C, Hölscher D (2003) Size and structure in fine root systems in old-growth and secondary tropical montane forests (Costa Rica). Biotropica 35:143-153

Holz I (2006) Epiphytic communities of bryophytes and macrolichens in a Costa Rican montane oak forest. In: Kappelle M (ed) Ecology and conservation of neotropical montane oak forests. Ecological Studies 185. Springer, Berlin, pp 83-98

IMN (Instituto Meteorológico Nacional) (1988) Catastro de las series de precipitaciones medidas en Costa Rica. MIRENEM (Ministerio de Recursos Naturales, Energia y Minas), San José, p 361

Kappelle M, Kennis PAF, De Vries RAJ (1995) Changes in diversity along a successional gradient in Costa Rican upper montane Quercus forest. Biodiv Conserv 4:10-34

Kappelle M, Geuze T, Leal ME et al (1996) Successional age and forest structure in a Costa Rican upper montane Quercus forest. J Trop Ecol 12:681-698

Kellman MC (1970) Secondary plant succession in tropical montane Mindanao. Publication BG/2, Research School of Pacific Studies. Australian National University, Canberra

Kennis PAF, De Vries RAJ (1993) Trends in diversity in mature and recovering montane Quercus forests, Cordillera de Talamanca, Costa Rica. M.Sc. thesis. Amsterdam University and Nijmegen Catholic University. Internal Report 289. Amsterdam, p 97

Kitayama K, Aiba S-I (2002) Ecosystem structure and productivity of tropical rain forests along altitudinal gradients with contrasting soil phosphorus pools on Mount Kinabalu, Borneo. J Ecol 90:37-51

Köhler L (2002) Die Bedeutung der Epiphyten im ökosystemaren Wasser- und Nährstoffumsatz verschiedener Altersstadien eines Bergregenwaldes in Costa Rica. Dissertation, Universität Göttingen

Köhler L, Hölscher D, Leuschner Ch (2006) Above-ground water and nutrient fluxes in three successional stages of montane oak forest with contrasting abundance of epiphytes in Costa Rica. In: Kappelle M (ed) Ecology and conservation of neotropical montane oak forests, Ecological Studies 185. Springer, Berlin, pp 271-282

Köhler L, Hölscher D, Leuschner Ch et al (2008) Biomass and water storage of epiphytes in old-growth and secondary montane rain forest stands in the Cordillera de Talamanca, Costa Rica. In: Bruijnzeel LA, Juvik J, Scatena FN et al (eds) Mountains in the Mist, Science for conserving and managing tropical montane cloud forests. University of Hawaii Publishers, Honolulu, Hawaii (in press)

Lamprecht H (1986) Silviculture in the Tropics. GTZ, Eschborn, pp 296 
McDonald MA, Healey JR (2000) Nutrient cycling in secondary forest in the Blue Mountains of Jamaica. For Ecol Manage 139:257-278

Medina E, Klinge H (1983) Productivity of tropical forests and tropical woodlands. In: Lange OL, Nobel PS, Osmond CB et al (eds) Encyclopedia of plant physiology Vol. 12D. Physiological plant ecology IV. Springer, Berlin, pp 281-303

Moser G, Hertel D, Leuschner Ch (2007) Altitudinal chance in LAI and stand leaf biomass in tropical montane forests: a transect study in Ecuador and a pan-tropical meta-analysis. Ecosystems 10:929-935

Nadkarni NM, Matelson TJ (1992) Biomass and nutrient dynamics of epiphytic litterfall in a neotropical montane forest, Costa Rica. Biotropica 24:24-30

Nadkarni N, Schaefer D, Matelson TJ et al (2004) Biomass and nutrient pools of canopy and terrestrial components in primary and secondary montane cloud forest, Costa Rica. For Ecol Manage 198:223-236

Ong JE, Gonk WK, Wong CH et al (1981) Productivity of a managed mangrove forest in West Malaysia. Proceedings of the international conference on trends in applied biology in South East Asia. University Sains Malaysis, Penang, Malaysia, pp 274-284

Proctor J (1983) Tropical forest litterfall. I. Problems of data comparison. In: Sutton SL, Whitmore TC, Chadwick AC (eds) Tropical rain forest: ecology and management.
Blackwell Scientific Publications. Oxford, England, pp 267-273

Proctor J, Anderson JM, Fogden SCL et al (1983) Ecological studies in four contrasting lowland rain forests in Gunung Mulu National Park, Sarawak: II. Litterfall, litter standing crop and preliminary observations on herbivory. J Ecol 71:261-283

Proctor J, Phillipps C, Duff GK et al (1989) Ecological studies on Gunung Silam, a small ultrabasic mountain in Sabah, Malaysia. II. Some forest processes. J Ecol 77:317-331

Röderstein M, Hertel D, Leuschner Ch (2005) Above- and below-ground litter production in three tropical montane forests in southern Ecuador. J Trop Ecol 21:483-492

Steinhardt U (1979) Untersuchungen über den Wasser- und Nährstoffhaushalt eines andinen Wolkenwaldes in Venezuela. Dissertation, Universität Göttingen

Tanner EVJ (1980) Litterfall in montane rain forests of Jamaica and its relation to climate. J Ecol 68:833-848

Van Uffelen JG (1991) A geological, geomorphological and soil transect study of the Chirripó massif and adjacent areas, Cordillera de Talamanca, Costa Rica. M.Sc. thesis. Wageningen Agricultural University. Internal report, p 72

Veneklaas EJ (1991) Litterfall and nutrient fluxes in two montane tropical rain forests, Colombia. J Trop Ecol 7:319-336

Whitmore TC (1998) An introduction to tropical rain forests. Oxford University Press, New York 